\title{
ВИКОРИСТАННЯ ЕЛЕМЕНТІВ ТЕНІСУ ЯК ЗАСОБУ ПІДВИЩЕННЯ ФІЗИЧНОЇ АКТИВНОСТІ ДІТЕЙ ПОЧАТКОВОЇ ШКОЛИ
}

\author{
Людмила Шуба ${ }^{1}$, Вікторія Шуба ${ }^{2}$ \\ 1Запорізький національний технічний університет, Запоріжжя, Україна, mila.shuba@gmail.com \\ ${ }^{2}$ Придніпровська державна академія фізичної культури і спорту, Дніпро, Україна, shubaV14@meta.ua
}

https://doi.org/10.29038/2220-7481-2019-04-74-81

\begin{abstract}
Анотації
Bcmyn. У наші дні серед дітей зростає популярність малорухомого способу дозвілля, що сприяє затримці розвитку фізичних якостей. Тому збереження й зміцнення здоров'я дітей початкової школи, підвищення рівня їхньої рухової активності, розвиток та вдосконалення фізичних якостей $є$ головними завданнями фізичного виховання дітей молодшого шкільного віку. Мета статті - обгрунтувати методику організації уроків фізичної культури для дітей молодшого шкільного віку з використанням елементів тенісу для підвищення рівня фізичної активності учнів. Організація дослідження. У досліджені взяло участь 64 учні (хлопці, дівчата) 8-9 років, стан здоров'я - основна медична група. Ми зберегли всі навчальні теми, години та структуру уроку, але розділили семестри на блоки. Для гармонійного розвитку дітей пропонуємо виконувати елементи тенісу та вправи обома руками. Використання елементів тенісу впроваджено в процес фізичного виховання на кожному уроці. Результати. Дослідили ефективність розробленої методики при порівняні показників контрольної та експериментальної груп. Виявлено, що в учнів експериментальних груп показники захворюваності значно менші завдяки використанню на уроках фізичної культури елементів тенісу. А рівень фізичної підготовленості дітей експериментальних груп відчутно підвищився, порівняно з представниками контрольних груп, а саме: сили м'язів кисті рук - у 6,33 та 3,21 раза (відповідно для хлопців та дівчат); швидкісно-силові здібності - у 5,34 та 4,19 раза; сили м'язів тулуба - у 4,94 та 4,07 раза; спритності - у 4,05 та 3,26 раза; гнучкості - у 5,14 та 6,18 раза; швидкості - у 3,01 та 2,59 раза. Висновки. Отримані результати свідчать про ефективність розробленої нами методики, яка спрямована на використання елементів тенісу під час уроків фізичної культури в початковій школі.
\end{abstract}

Ключові слова: методика, здоров'я, початкова школа, фізична активність, фізичні якості.

Людмила Шуба, Виктория Шуба. Использование элементов тенниса как средства повышения физической активности детей начальной школы. Вступление. В наши дни среди детей растет популярность в малоподвижном образе отдыха, что способствует задержке развития физических качеств. Поэтому сохранение и укрепление здоровья детей начальной школы, повышение уровня их двигательной активности, развитие и усовершенствование физических качеств является основной задачей физического воспитания детей младшего школьного возраста. Цель статьи - обосновать методику организации уроков физической культуры для детей младшего школьного возраста при использовании элементов тенниса для повышения уровня физической активности учеников. Организация исследования. В исследовании приняло участие 64 ученика (мальчики, девочки) 8-9 лет, по состоянию здоровья - основная медицинская группа. Мы сохранили все учебные темы, часы и структуру урока, но поделили семестры на блоки. Для гармоничного развития ребенка предлагаем использовать элементы тенниса и упражнения двумя руками. Элементы тенниса использовались на каждом уроке. Результаты. Изучили эффективность разработанной методики при сравнении показателей контрольной и экспериментальной групп. Определили, что в учеников экспериментальных групп показатели заболеваемости значительно меньше, благодаря использованию на уроках физической культуры элементов тенниса. А уровень физической подготовленности детей экспериментальных групп больше повысился, нежели у представителей контрольных групп. А именно: сила мышц кисти - в 6,33 и 3,21 раза (соответственно мальчики и девочки); скоростно-силовые способности - в 5,34 и 4,19 раза; сила мышц туловища - в 4,94 и 4,07 раза; ловкость - в 4,05 и 3,26 раза; гибкость - в 5,14 и 6,18 раза; скорость - в 3,01 и 2,59 раза. Выводы. Полученные результаты свидетельствуют об эффективности разработанной нами методики, которая направлена на использование элементов тенниса во время уроков физической культуры в начальной школе.

Ключевые слова: методика, здоровье, начальная школа, физическая активность, физические качества.

Liudmyla Shuba, Viktoriia Shuba. Using of Tennis Elements as a Way to Increase Physical Activity of Primary School Children. Introduction. Nowadays the sedentary lifestyle is increasing among children which influence for delayed development of physical qualities. That's why preserving and improving the health of primary school children, increasing their physical activity, development and improvement of physical qualities is the main task of physical education of primary school children. The Purpose of the Research - substantiate the methodology of 
organization physical education lessons for primary school children using tennis elements to improve physical activity level. Research Organization. In the study involved 64 children (boys and girls) 8-9 years old. Children are assigned to the main medical group for health reasons. We saved all the study topics, hours and lessons structure, but divided the semesters into blocks. For a harmonious development, we performed elements and exercise with both right and left hands. Using of tennis elements was introduced into the process of physical education in each lessons. Results of the Research. Investigated the effectiveness of the developed methodology comparing the results of the control and experimental group. Determined that the children of the experimental group had significantly lower level of health problems due to the use of tennis elements at physical education lessons. And the results of the physical fitness level were significantly better. Namely: muscular strength of hands increased 6,33 and 3,21 times (respectively for boys and girls); speed-strength physical qualities - 5,34 and 4,19 times, torso muscle strength - 4,94 and 4,07 times; manual dexterity $-4,05$ and 3,26 times; flexibility - 5,14 and 6,18 times; speed - 3,01 and 2,59 times. Conclusion. The results show the effectiveness of the developed methodology, which is aimed at the use of tennis elements during physical education lessons in the primary school.

Key words: methodology, health, primary school, physical activity, physical skills.

Вступ. Галузь фізичної культури у сфері освіти проходить діяльний період становлення, який відбувається також у багатьох сферах діяльності суспільства. Поточні тенденції й активна динаміка розвитку галузі, зростаюче значення виконуваних нею функцій сприяють формуванню законодавчої й нормативно-правової бази. Законодавче регулювання відносин у сфері фізичної культури здійснюється Конституцією України, Законом України «Про фізичну культуру і спорт», Законом України «Про освіту», Міжгалузевою комплексною програмою «Здоров’я нації», іншими законодавчими актами України $[13 ; 15]$.

Забезпечення здоров'я, формування здорового способу життя - це проблема багатофакторна. Фізична активність є одним із головних аспектів здорового способу життя. Вона робить людину не лише фізично більш привабливою, але й покращує здоров’я та позитивно впливає на подальше життя [2; 3; 6; 14]. На сучасному етапі перед нашою державою продовжує достатньо гостро стояти проблеми здоров'я підростаючого покоління. Це пов'язано з тим, що сучасні гаджети сприяють популяризації малорухомого способу дозвілля та й під час перерв у школі діти віддають перевагу занурюванню в Інтернет [6;16; 18]. За період навчання дітей у початковій школі в 3-4 рази зменшується кількість здорових дітей, збільшується нестача рухової активності, що сприяє затримці розвитку таких фізичних якостей, як сила, швидкість, витривалість, гнучкість, спритність [5; 7; 8]. Тому, одним із підходів до розв'язання проблеми реалізації потенціальних можливостей організму дітей може стати будова процесу фізичного виховання молодших школярів на підставі використання елементів тенісу. Завдяки цьому виду спорту досягається розвиток рухових якостей i координаційних здібностей дітей, розширюється фонд їхніх рухових умінь і навичок, а також значно збільшується резерв функціональних систем організму.

У роботах Л. Шуби [13], C. Felfe, M. Lechner, \& A. Steinmayr [4], J. Wojnar, N. Macarenco, D. Nawarecki, E. Menshyh, Y. Petrenco, \& B. Pustovalov [20] установлено інтеграцію пізнавальної й рухової діяльності в системі навчання та виховання школярів; Т. Круцевич [15], J. Winnick, X. Short [19], M. Reiman, R. Manske [10] - систематизацію досліджень, котрі використовують для визначення рівня фізичного розвитку, фізичної підготовленості та функціонального стану дітей і спортсменів. Е. Вільчковський, Б.Шиян, А. Цьось, В. Пасічнік [17] на основі вивчення сучасного стану фізичного виховання в школі розглянули шляхи формування національної системи фізичного виховання школярів; R. Apache [1] та H. Williams, K. Pfeiffer, J. O’Neill, M. Dowda, K. McIver, W. Brown [18] установили різновиди рухової активності і їі вплив на розвиток рухових якостей; J. Fisher, L. Reilly, C. Kelly, A. Montgomery, J. Williamson [5] та J. Rink [11], M. Schmidt, F. Egger, V. Benzing, K. Jäger, A. Conzelmann, C. Roebers, C. Pesce [12] - вплив загальних форм, методів і принципів на розвиток рухливих умінь та навичок, які сприяють підвищенню рівня рухової активності дітей молодшого шкільного віку. У цих дослідженнях відображено основні аспекти впливу різноманітних шляхів використання фізичного виховання для гармонійного розвитку підростаючої особистості.

Тому збереження й зміцнення здоров’я дітей початкової школи, підвищення рівня їхньої рухової активності, розвиток та вдосконалення фізичних якостей є головними завданнями фізичного виховання дітей молодшого шкільного віку. Ураховуючи вищенаведене, відзначаємо, що тема дослідження $є$ актуальною та своєчасною.

Мета дослідження - обгрунтувати методику організації уроків фізичної культури для дітей молодшого шкільного віку з використанням елементів тенісу для підвищення рівня фізичної активності учнів. 
Матеріали й методи дослідження. Учасники. Дослідження проводили з вересня 2017 р. до травня 2018 р. на базі Запорізького навчально-виховного комплексу (ЗНВК) «Вибір». У ньому взяли участь 64 учні (хлопці, дівчата) 8-9 років, які були поділені на експериментальні та контрольні групи. В експерименті взяли участь учні, які за станом здоров'я віднесені до основної медичної групи, а також писали правою рукою (ця особливість пов'язана 3 тим, щоб групи були однорідними у зв'язку 3 використанням елементів тенісу й обраними тестами).

Організачія дослідження. Наша методика під час розробки спиралася за моделлю «на базі стандартів» відповідно до Державного стандарту початкової загальної освіти, затвердженого Постановою Кабінету Міністрів України № 462 від 20.04.2011 р. Акцентовано на розвитку навичок мислення, міжособистісних відносин, творчої співпраці всіх учасників навчально-виховного процесу й покликані сприяти системним реформам національної освіти, процесам її інтеграції до європейського та всесвітнього освітнього простору. Ми зберегли всі навчальні теми, години й структуру уроку, але розділили семестри на блоки (I семестр складається з двох блоків, II - із трьох). Одна частина семестру проходить на спортивному майданчику - на відкритому повітрі, а друга - у спортивному залі. Використання елементів тенісу впроваджувалося в процес фізичного виховання на кожному уроці.

Для гармонійного розвитку дітей ми пропонуємо виконувати елементи та вправи як правою, так і лівою руками. Ігрові стійки й пересування (напрямки пересування розподіляються таким чином: $16 \%-$ біг уперед; $13 \%$ - біг уперед-праворуч; $17 \%$ - біг праворуч; $18 \%$ - біг ліворуч; $12 \%$ - біг упередліворуч; $5 \%$ - біг назад; $11 \%$ - біг назад-уліво; $7 \%$ - біг назад-праворуч і $1 \%$ - біг по дузі). Вправи 3 ракеткою (вправи з ракеткою сприяють розвитку рухливості в променево-зап'ястних, ліктьових, плечових суглобах і зміцненню м'язів, що беруть участь у цих рухах; вправи ми виконували не лише з маленькими тенісними ракетками, а й із гімнастичними палицями, «пушками» та ракетками для малого тенісу). Вправи з ракеткою й м'ячем (вправи з м'ячем у простих умовах розвивають координацію рухів. Потрібно навчитися дуже уважно слідкувати за м'ячем і під час його польоту, а особливо ловлі, ловити м'яч і правою, і лівою руками) [13].

Реалізуючи завдання нашої методики, для більш якісного та ефективного розвитку фізичних якостей ми використовували такі типи занять: навчально-тренувальне заняття - виконуються завдання рухових умінь і навичок, розвитку фізичних якостей, удосконалювання умінь та навичок (50 \% усіх занять); ігрове заняття - побудоване на основі різноманітних рухливих ігор, ігор-естафет, ігор-атракціонів [9]; комплексне заняття - спрямоване на синтез різних видів діяльності; контрольне заняття проводиться наприкінці теми та спрямоване на кількісну і якісну оцінку рухової підготовленості дітей.

На кожному занятті виконують три основні види рухів. Їх повторюють у певній послідовності, ускладнюючи та варіюючи через порівняно невеликий інтервал часу.

У дослідженні використано тести загальної фізичної підготовки: човниковий біг 4x9, біг 30 м, стрибок у довжину з місця, Згинання та розгинання рук в упорі лежачи, м'язів - згиначів кисті правої руки, нахил тулуба вперед із положення сидячи, піднімання тулуба в сід за 1 хв, м'язів - згиначів кисті лівої руки $[10,15,19]$. Результати за всіма нашими тестами були переведені в 5-бальну систему. Це пов'язоно з тим, що в молодшому шкільному віці дітям буде краще орієнтуватись у динаміці своїх досягнень.

Протягом дослідження аналізували показники захворюваності методом аналізу медичних карток школярів, медичних довідок про звільнення від уроків фізичної культури. Захворюваність оцінювали за допомогою підрахунку кількості днів, пропущених через хворобу за місяць, за семестр, за рік.

Статистичний аналіз.. Результати за всіма нашими тестами переведені 5- бальну систему, яку ми розробили самі. Але під час розробки ми спиралися на стандарти фізичної підготовленості населення України. Також ми використовували коефіцієнт варіації для того, щоб знати, наскільки вибірка є однорідною. Статистичний аналіз даних здійснювався за використання програми SPSS Statistica.

Результати дослідження. Дослідили ефективність розробленої методики, порівнюючи показники контрольної та експериментальної груп.

Аналізуючи показники пропуску навчальних днів за захворюванням, відзначаємо, що для першого семестру найбільш проблематичним був жовтень. Діти вже адаптувалися до робочого графіка, але перепади температури та «бабине літо» можуть бути причинами захворювання. Найбільш критичним семестром у навчальному році $є$ другий, що пов'язано з епідеміологічним станом у цей період (табл. 1). Захворюваність дітей на інфекційні хвороби не однакова в різні сезони року: вона менша в осінній період року, але збільшується до зимового й початку весняного періодів. У зв'язку зі зменшеною освітленістю, зниженням температури середовища в зимовий період відбувається падіння адаптивних 
можливостей організму дитини. Саме тому важливо не ігнорувати профілактично-оздоровчими засобами фізичного виховання, які дають можливість підтримати та адаптувати дитячий організм до різних кліматичних проявів. Завдяки використанню нашої методики ми змогли зменшити відсоток захворюваності в другому семестрі.

Табличя 1

Відсоткове співвідношення пропущених днів через хворобу учнів за семестрами

\begin{tabular}{|c|c|c|c|c|}
\hline \multirow{2}{*}{ Група } & \multirow{2}{*}{ Клас } & 1 семестр & 2 семестр & Усього за рік \\
\hline & & \multicolumn{3}{|c|}{$\%$} \\
\hline \multirow{2}{*}{ Експериментальні } & Хлопці (n=17) & \multirow{2}{*}{41,33} & \multirow{2}{*}{52,49} & \multirow{2}{*}{46,91} \\
\hline & Дівчата $(\mathrm{n}=15)$ & & & \\
\hline \multirow{2}{*}{ Контрольні } & Хлопці (n=18) & \multirow{2}{*}{45,28} & \multirow{2}{*}{65,37} & \multirow{2}{*}{55,32} \\
\hline & Дівчата (n=14) & & & \\
\hline
\end{tabular}

У табл. 2 та 3 ми демонструємо результати, отримані під час упровадження нашої методики.

Результати тестів до та після експерименту КГ й ЕГ, \%, хлопчики

Таблиия 2

\begin{tabular}{|c|c|c|c|c|c|c|c|c|c|c|c|c|c|c|c|c|c|c|c|c|}
\hline \multirow[t]{4}{*}{ Tec } & \multicolumn{4}{|c|}{1} & \multicolumn{4}{|c|}{2} & \multicolumn{4}{|c|}{3} & \multicolumn{4}{|c|}{4} & \multicolumn{4}{|c|}{5} \\
\hline & \multicolumn{2}{|c|}{$\mathbf{K \Gamma}$} & \multicolumn{2}{|c|}{$\mathbf{E} \Gamma$} & \multicolumn{2}{|c|}{$\mathbf{K \Gamma}$} & \multicolumn{2}{|c|}{$\mathbf{E \Gamma}$} & \multicolumn{2}{|c|}{$\mathbf{K \Gamma}$} & \multicolumn{2}{|c|}{$\mathbf{E \Gamma}$} & \multicolumn{2}{|c|}{$\mathbf{K \Gamma}$} & \multicolumn{2}{|c|}{$\mathbf{E \Gamma}$} & \multicolumn{2}{|c|}{$\mathbf{K \Gamma}$} & \multicolumn{2}{|c|}{$\mathbf{E \Gamma}$} \\
\hline & 음 & 氕 & 음 & 氕 & 울 & 氕 & 움 & 馬 & 음 & 氕 & 电 & 氖 & 음 & 氕 & 음 & 氖 & $\stackrel{\theta}{\theta}$ & & 욤 & 㞼 \\
\hline & \multicolumn{20}{|c|}{ експерименту } \\
\hline $\begin{array}{l}\text { Човниковий } \\
\text { біг } 4 \times 9\end{array}$ & 11 & - & 12 & - & 31 & 2 & 30 & - & 54 & 55 & 55 & 34 & 4 & 34 & 3 & 45 & - & 9 & - & 21 \\
\hline Біг $30 \mathrm{M}$ & 13 & - & 10 & - & 29 & - & 25 & - & 51 & 61 & 59 & 22 & 7 & 28 & 6 & 54 & - & 11 & - & 24 \\
\hline $\begin{array}{l}\text { Стрибок } \\
\text { у довжину } \\
3 \text { місця }\end{array}$ & 9 & - & 8 & - & 34 & - & 35 & - & 46 & 66 & 48 & 23 & 11 & 27 & 9 & 52 & - & 7 & - & 25 \\
\hline $\begin{array}{l}\text { Згинання } \\
\text { та розгинання } \\
\text { рук в упорі } \\
\text { лежачи }\end{array}$ & 18 & - & 16 & - & 36 & 4 & 37 & 3 & 40 & 69 & 43 & 36 & 6 & 22 & 4 & 42 & - & 5 & - & 19 \\
\hline $\begin{array}{l}\text { М'язів - } \\
\text { згиначів кисті } \\
\text { правої руки }\end{array}$ & 8 & - & 10 & - & 30 & - & 28 & - & 51 & 47 & 55 & 15 & 11 & 43 & 7 & 62 & - & 10 & - & 23 \\
\hline $\begin{array}{l}\text { Нахил тулуба } \\
\text { вперед із } \\
\text { положення } \\
\text { сидячи }\end{array}$ & 10 & - & 12 & - & 34 & - & 31 & - & 51 & 49 & 53 & 17 & 5 & 39 & 4 & 57 & - & 12 & - & 26 \\
\hline $\begin{array}{l}\text { Піднімання } \\
\text { тулуба в сід } \\
\text { за } 1 \text { хв }\end{array}$ & 17 & - & 18 & - & 31 & 3 & 28 & 2 & 49 & 67 & 50 & 33 & 3 & 24 & 4 & 44 & - & 6 & - & 21 \\
\hline $\begin{array}{l}\text { М'язів - } \\
\text { згиначів кисті } \\
\text { лівої руки }\end{array}$ & 15 & - & 15 & - & 37 & 28 & 38 & 23 & 46 & 56 & 44 & 45 & 2 & 10 & 3 & 21 & - & 6 & - & 1 \\
\hline
\end{tabular}

Отримані дані (коефіцієнт варіації) свідчать, що групи є більш однорідними за контрольні й експериментальні обох статей, але не у всіх тестах. За показниками тестів «човниковий біг $4 \times 9$ м» (КГ: $\mathrm{V}$ - 8,91 - хлопці, V - 9,01 \% - дівчата; ЕГ: V- 7,03 \% - хлопці, V - 8,11 \% - дівчата), «біг 30 м» (КГ: $\mathrm{V}$ - 6,39 \% - хлопці, V - 6,33 \% - дівчата; ЕГ: V - 6,26 \% - хлопці, V - 6,78 \% - дівчата), «стрибок у довжину з місця» (КГ: V - 7,34 \% - хлопці, V - 7,82 \% - дівчата; ЕГ: V - 7,12 \% - хлопці, V - 8,04 \% дівчата), «нахил тулуба вперед із положення сидячи» (КГ: V - 6,02 \% - хлопці, V - 7,11 \% - дівчата; ЕГ: $\mathrm{V}-6,81 \%$ - хлопці, $\mathrm{V}-6,12 \%$ - дівчата), «м'язів - згиначів кисті правої руки» (КГ: V - 9,45 \% хлопці, $\mathrm{V}$ - 9,11 \% - дівчата; ЕГ: $\mathrm{V}$ - 8,28 \% - хлопці, $\mathrm{V}$ - 8,48 \% - дівчата). 
Для тестів «згинання та розгинання рук в упорі лежачи» (КГ: $\mathrm{V}-13,58 \%$ - хлопці, $\mathrm{V}-12,69 \%-$ дівчата; ЕГ: V - 12,27 \% - хлопці, V - 13,08 \% - дівчата), «піднімання тулуба із положення лежачи протягом 1 хв» (КГ: V - 13,72 \% - хлопці, V - 13,22 \% - дівчата; ЕГ: V - 14,11 \% - хлопці, V - 14,02 \% - дівчата), «м'язів - згиначів кисті лівої руки» (КГ: V - 11,20 \% - хлопці, V - 12,04 \% - дівчата; ЕГ: V $10,52 \%$ - хлопці, $\mathrm{V}-11,63 \%$ - дівчата) коливання результатів вимірів були середніми.

Таблиия 3

Результати тестів до та після експерименту КГ й ЕГ, \%, дівчата

\begin{tabular}{|c|c|c|c|c|c|c|c|c|c|c|c|c|c|c|c|c|c|c|c|c|}
\hline \multirow{4}{*}{ Тест } & \multicolumn{4}{|c|}{1} & \multicolumn{4}{|c|}{2} & \multicolumn{4}{|c|}{3} & \multicolumn{4}{|c|}{4} & \multicolumn{4}{|c|}{5} \\
\hline & \multicolumn{2}{|c|}{ КГ } & \multicolumn{2}{|c|}{$\mathbf{E} \Gamma$} & \multicolumn{2}{|c|}{ КГ } & \multicolumn{2}{|c|}{$\mathbf{E} \Gamma$} & \multicolumn{2}{|c|}{ КГ } & \multicolumn{2}{|c|}{$\mathbf{E \Gamma}$} & \multicolumn{2}{|c|}{ КГ } & \multicolumn{2}{|c|}{$\mathbf{E \Gamma}$} & \multicolumn{2}{|c|}{ КГ } & \multicolumn{2}{|c|}{$\mathbf{E \Gamma}$} \\
\hline & 욤 & 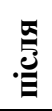 & 昌 & 离 & $\stackrel{\theta}{1}$ & 氖 & 是 & $\stackrel{\breve{s}}{\breve{b}}$ & 是 & 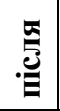 & 是 & 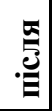 & 尺 & $\stackrel{5}{5}$ & $\stackrel{乛}{*}$ & $\stackrel{\square}{\breve{e}}$ & $\stackrel{\theta}{\theta}$ &  & $\stackrel{\varrho}{1}$ & 氖 \\
\hline & & & & & & & & & екс & тери & мент & & & & & & & & & \\
\hline $\begin{array}{l}\text { Човниковий } \\
\text { біг } 4 \mathrm{x} 9\end{array}$ & 10 & - & 13 & - & 29 & 2 & 27 & - & 56 & 56 & 57 & 35 & 5 & 34 & 3 & 44 & - & 8 & - & 21 \\
\hline Біг $30 \mathrm{~m}$ & 11 & - & 12 & - & 31 & - & 32 & - & 50 & 63 & 47 & 23 & 8 & 27 & 9 & 56 & - & 10 & - & 21 \\
\hline $\begin{array}{l}\text { Стрибок } \\
\text { у довжину } \\
3 \text { місця }\end{array}$ & 10 & - & 9 & - & 36 & - & 38 & - & 44 & 68 & 42 & 23 & 10 & 26 & 11 & 53 & - & 6 & - & 24 \\
\hline $\begin{array}{l}\text { Згинання } \\
\text { та розгинання } \\
\text { рук в упорі } \\
\text { лежачи }\end{array}$ & 19 & - & 18 & - & 37 & 5 & 36 & 3 & 40 & 70 & 41 & 37 & 4 & 19 & 5 & 40 & - & 6 & - & 20 \\
\hline $\begin{array}{l}\text { М'язів - } \\
\text { згиначів кисті } \\
\text { правої руки }\end{array}$ & 11 & - & 9 & - & 32 & - & 31 & - & 49 & 48 & 50 & 14 & 8 & 42 & 10 & 62 & - & 10 & - & 24 \\
\hline $\begin{array}{l}\text { Нахил тулуба } \\
\text { вперед і3 по- } \\
\text { ложення } \\
\text { сидячи. }\end{array}$ & 8 & - & 7 & - & 29 & - & 30 & - & 52 & 47 & 53 & 15 & 11 & 42 & 10 & 58 & - & 11 & - & 27 \\
\hline $\begin{array}{l}\text { Піднімання } \\
\text { тулуба в сід } \\
\text { за } 1 \text { хв }\end{array}$ & 18 & - & 19 & - & 35 & 4 & 34 & 2 & 44 & 68 & 45 & 35 & 3 & 23 & 2 & 44 & - & 5 & - & 19 \\
\hline $\begin{array}{l}\text { М'язів - } \\
\text { згиначів кисті } \\
\text { лівої руки }\end{array}$ & 18 & 6 & 19 & 1 & 41 & 33 & 40 & 28 & 37 & 52 & 37 & 52 & 4 & 7 & 4 & 13 & - & 2 & - & 6 \\
\hline
\end{tabular}

Під час бального аналізу показників до експерименту відзначаємо, що всі дані контрольної та експериментальної груп розміщувалися на відмітці від 1 до 4 балів. Але показники були більш зосереджені на балах від 2 до 4, відсоткове співвідношення було майже однакове.

Під час аналізу бальної оцінки показників після експерименту відзначаємо, що дані перемістилися: контрольна група й експериментальна групи розміщувалися на відмітці від 2 до 5 балів майже у всіх тестах. Але показники експериментальної групи виявилися вищими.

Темпи приросту показників результатів тестів фізичної підготовленості дітей експериментальної групи були значно вищими, порівняно з представниками контрольної групи, а саме: сила м'язів кисті рук - у 6,33 та 3,21 раза (відповідно для хлопців та дівчат); швидкісно-силових фізичних якостей - у 5,34 і 4,19 раза; сили м'язів тулуба - у 4,94 та 4,07 раза; спритності - у 4,05 і 3,26 раза; гнучкості - у 5,14 та 6,18 раза; швидкості - у 3,01 та 2,59 раза.

Ураховуючи отримані показники, ми вважаємо, що треба зупинитися на показниках гнучкості й сили у зв'язку з тим, що ми отримали дуже цікаві результати. Під час побудови нашої методики ми врахували сенситивний період розвитку фізичних якостей i завдяки використанню правильно підібраних вправ й елементів із тенісу відбувся максимально можливий приріст показників сили та гнучкості. Аналізуючи вищенаведене, відзначаємо, що розроблена нами методика $є$ ефективною та має право на існування.

Дискусія. Результати Всеукраїнського опитування свідчать, що на початку XXI ст. достатній рівень оздоровчої рухової активності мали лише 3 \% населення віком від 16 до 74 років; середній (2-3 заняття 
на тиждень) - 6 \%; низький рівень (1-2 заняття на тиждень) - 33 \%; населення. Ураховуючи статистичні дані, бачимо, що великого значення в наш час набуває питання ефективності різних методик проведення уроку фізичної культури [2, 4, 12]. На нашу думку, ефективним засобом покращення рівня здоров’я учнів, комплексного розвитку всіх рухових функцій, підвищення мотивації до занять фізичними вправами може стати саме використання елементів тенісу [13]. У нашій методиці ми врахували певну послідовність, зважаючи на ускладнення видів діяльності учнів (репродуктивна, продуктивна, творча); особливостей психічних процесів; особливостей діяльності учня залежно від характеру знань, які засвоюються.

Аналізуючи показники табл. 1, відзначаємо, що ці дані повинні бути в полі зору вчителів, батьків, спеціалістів із фізичної культури, оскільки вимагають постійної корекції та профілактики, а також розробки програм із підвищення захисних властивостей організму, загального фізичного статусу 3 метою зміцнення здоров'я. Отримано дані про те, що ми не лише підтвердили дослідження вчених [5; $16 ; 20]$, але й доповнили їх.

Раціонально організований процес фізичного виховання повинен бути спрямований на різнобічний та одночасно пропорційний розвиток рухових якостей. Високі показники фізичної підготовленості слугують функціональним фундаментом для розширення фонду рухових умінь та навичок, а також значно збільшують резерв функціональних систем організму. Найпоширенішим і доступним методом педагогічного контролю є рухові тести. Фізична підготовленість досліджуваних визначалася за результатами педагогічного тестування, яке показало рівень основних рухових якостей: гнучкості, сили, витривалості, швидкості, швидкісно-силових якостей. Отриманні дані (табл. 2 та 3) у процесі дослідження свідчать, що рівень фізичної підготовленості на початку дослідження був однаковий у всіх групах незалежно від статті. Аналіз бальної оцінки показників після експерименту продемонстрував, що дані контрольних й експериментальних груп розміщувалися на відмітці від 2 до 5 балів майже у всіх тестах. В експериментальних групах (хлопці, дівчата) - показники покращилися на 42,06 \%, у контрольних групах (хлопці, дівчата) показники покращилися на 21,38 \%. Показники експериментальної групи дали більш позитивний приріст завдяки розробленій методиці.

Отримані під час упровадження методики дані свідчать про те, що ми не лише підтвердили дослідження вчених [3; 4; 15], але й доповнили їх відсотковим співвідношенням до та після експерименту контрольної й експериментальної груп.

Аналізуючи вищенаведені показники, відзначаємо, що розроблена методика справді має позитивний характер та може використовуватися під час навчальних занять для дітей початкової школи.

Висновки. Установлена проблемність досліджуваного питання дала змогу визначити й розробити експериментальну методику використання елементів тенісу під час уроків фізичної культури для навчання руховим умінь та навичок учнів початкової школи.

Визначено, що найбільша кількість пропущених навчальних днів через хворобу в навчальному році припадає на другий семестр. Це пов'язано зі зниженням імунітету, унаслідок чого виникають вірусні та загально-респіраторні захворювання.

Якісна характеристика рівня фізичної підготовленості показала, що використання експериментальної методики практично за всіма показниками забезпечило досягнення найбільш високих значень нормативів фізичної підготовленості.

Аналізуючи вищенаведені показники, відзначаємо, що розроблена методика справді має позитивний характер та може використовуватися під час навчальних занять для дітей початкової школи.

Щодо конфлікту інтересів, автори заявляють, що його не існує.

\section{Джерела та література}

1. Apache R. R. Activity-based intervention in motor skill development. Percept Mot Skills. 100 (3 Pt 2). 2005. $1011-20$.

2. Арефьєв, В. Г. Педагогічні технології реалізації диференційованого фізичного виховання учнів основної школи. Науковий часопис Наиіонального педагогічного університету імені М. П. Драгоманова. Серія 15: Науково-педагогічні проблеми фізичної культури / фізична культура і спорт: зб. наук. праџь. Київ: Вид-во НПУ ім. М. П. Драгоманова. 2017. Вип. 3 К (84). С. 29-33.

3. Evans J., Davies B., \& Wright J. Body knowledge and control. Studies in the sociology of physical education and health. London, England: Routledge, 2004. 100-105.

4. Felfe C., Lechner M., \& Steinmayr ASport and Child Development. CESifo Working Papers. 2011. 3629.

5. Fisher J.J., Reilly L.A., Kelly C., Montgomery A., Williamson J.Y. Fundamental movement skills and habitual physical activity in young children. Med Sci Sports Exerc. 2005. 37. 684-688. 
6. Gaetano A. Relationship between physical inactivity and effects on individual health status. Journal of Physical Education and Sport. 2016. 16 Supplement issue 2. Art 170. 1069-1074. doi.org/10.7752/ jpes.2016.s2170.

7. Ghyppo, A., Tkachov, S. \& Orlenko, O. Role of physical education on the formation of a healthy lifestyle outside of school hours. Journal of Physical Education and Sport. 2016. 16(2). 335-339.

8. Kirk D. Physical education future.es. London, England: Routledge. 2010. 45-51.

9. Kuffner T. The Fitness Fun Busy Book: 365 Creative Game \&Active to Keep Your Child Moving and Learning. Meadowbrook Press. 2013. 351.

10. Reiman M. P., Manske R. C. Functional Testing in Human Performance. Champaign, IL.: Human Kinetics. 2008. 308.

11. Rink J. E. Designing the physical education curriculum: promoting active life styles. Boston, McGraw-Hill Higher Education. 2009. 250.

12. Schmidt M., Egger F., Benzing V., Jäger K., Conzelmann A., Roebers C. M., \& Pesce C. Disentangling the relationship between children's motor ability, executive function and academic achievement. PLoS one. 2017. 12(8). e0182845. doi.org/10.1371/journal.pone.0182845

13. Шуба Л. В. Формування рухових вмінь та навичок учнів початкової школи у процесі занять тенісом: [монографія]. Запоріжжя: ТОВ «ЛІПС» ЛТД. 2015. 144.

14. Shuba L. V. Modern approach to implementation of health related technology for primary school children. Pedagogics, psychology, medical-biological problems of physical training and sports. 2016. 2. 66-71. doi. org/10.15561/18189172.2016.0210

15. Теорія і методика фізичного виховання: підручник для студентів ВНЗ фіз. виховання і спорту/за ред. Т. Ю. Круцевич. Київ: Нац. ун-т фіз. виховання і спорту, вид-во Олімп. літ. 2017. Т. 2. 448 с.

16. Van der Niet A. G., Hartman E., Smith J., \& Visscher C. Modeling relationships between physical fitness, executive functioning, and academic achievement in primary school children. Psychology of Sport and Exercise. 2014. 15(4). 319-325. doi.org/10.1016/j.psychsport.2014.02.010

17. Вільчковський Е. С., Шиян Б. М., Цьось А. В., Пасічник В. Р. Система фізичного виховання учнів загальноосвітніх шкіл Польщі та України (XVI- початок XXI століття): порівняльний аналіз: монографія. Луцьк: Вежа Друк. 2016. 240 с.

18. Williams H. G., Pfeiffer K. A., O’Neill J. R., Dowda M., McIver K. L., Brown W. H. Motor skill performance and physical activity in preschool children. Obesity (Silver Spring). 2008. 16. 121-126.

19. Winnick J., Short X. Brockport Physical Fitness Test Manual-2nd Edition with Web resource: A HealthRelated Assessment for Youngsters with Disabilities. Human Kinetics. 2nd edition. 2014. 160.

20. Wojnar J., Macarenco N., Nawarecki D., Menshyh E., Petrenco Y., \& Pustovalov B. Sense-motor reactivity and physical development of schoolchildren. Annales Universitatis Mariae Curie-Sklodowska. Promocja zdorowia w hierarchii wartosci. 2006. № 8. 325-331.

\section{References}

1. Apache, R. R. (2005). Activity-based intervention in motor skill development. Percept Mot Skills, 100 (3 Pt 2): 1011-20.

2. Arefiev, V. H. (2017). Pedahohichni tekhnolohii realizatsii dyferentsiiovanoho fizychnoho vykhovannia uchniv osnovnoi shkoly. [Pedagogical technologies of realization of the differentiated physical education students basic school]. Vyd-vo NPU Naukovyi chasopys NPU imeni M. P. Drahomanova, Vyp. 3K, $29-33$. http://enpuir.npu.edu.ua/handle/123456789/16820

3. Evans, J., Davies, B., \& Wright, J. (2004). Body knowledge and control. Studies in the sociology of physical education and health. London, England: Routledge, 100-105.

4. Felfe, C., Lechner, M., \& Steinmayr, A. (2011). Sport and Child Development. CESifo Working Papers, 3629.

5. Fisher, J. J., Reilly, L. A., Kelly, C., Montgomery, A., Williamson, J. Y. (2005). Fundamental movement skills and habitual physical activity in young children. Med Sci Sports Exerc, 37. 684-688.

6. Gaetano, A. (2016). Relationship between physical inactivity and effects on individual health status. Journal of Physical Education and Sport, 16 Supplement issue 2, Art 170, 1069-1074. doi:10.7752/jpes.2016.s2170.

7. Ghyppo, A., Tkachov, S. \& Orlenko, O. (2016). Role of physical education on the formation of a healthy lifestyle outside of school hours. Journal of Physical Education and Sport, 16(2), 335-339.

8. Kirk, D. (2010). Physical education futures. London, England: Routledge, 45-51.

9. Kuffner, T. (2013). The Fitness Fun Busy Book: 365 Creative Game \&Active to Keep Your Child Moving and Learning. Meadowbrook Press, 351.

10. Reiman, M. P., Manske, R. C. (2008). Functional Testing in Human Performance. Champaign, IL.: Human Kinetics, 308.

11. Rink, J. E. (2009). Designing the physical education curriculum: promoting active life styles. Boston, McGraw-Hill Higher Education, 250. 
12. Schmidt, M., Egger, F., Benzing, V., Jäger, K., Conzelmann, A., Roebers, C. M., \& Pesce, C. (2017). Disentangling the relationship between children's motor ability, executive function and academic achievement. PLoS one, 12(8), e0182845. doi.org/10.1371/journal.pone.0182845

13. Shuba, L. V. (2015) Formuvannya ruxovy`x umin` ta navy`chok uchniv pochatkovoyi shkoly`u procesi zanyat tenisom: [monografiya] [The formation of motor skills in physical training lessons for children of primary school age with use of tennis elements[monograph]. Zaporizhzhya: TOV «LIPS» LTD. 144.

14. Shuba, L. V. (2016) Modern approach to implementation of health related technology for primary school children. Pedagogics, psychology, medical-biological problems of physical training and sport, 2, 66-71. doi. org/10.15561/18189172.2016.0210

15. Teoriia i metodyka fizychnoho vykhovannia: pidruchnyk dlia stud. vyshch. navch. zakladiv fiz. vykhovannia i sportu [Theory and methodology of physical education: book for students of university with a focus on physical education and sport]/za red. T. Yu. Krutsevych (2017). Kyiv: Natsionalnyi universytet fizychnoho vykhovannia i sportu Ukrainy, vyd-vo Olimp. Lit., T. 2, 448.

16. Van der Niet, A. G., Hartman, E., Smith, J., \& Visscher, C. (2014). Modeling relationships between physical fitness, executive functioning, and academic achievement in primary school children. Psychology of Sport and Exercise, 15(4), 319-325. doi.org/10.1016/j.psychsport.2014.02.010

17. Vilchkovskyi, E. S., Shyian, B. M., Tsos, A. V., Pasichnyk, V. R. (2016). Systema fizychnoho vyhovannia uchniv zahalnoosvitnikh shil Polshchi ta Ukrainy (XVI-pochatok XXI stolittia): porivnialnyi analiz: monohrafia [The system of physical education of students of secondary school in Poland and Ukraine (XVI-the beginning of XXI century): a comparative analysis]. Lutsk: Vezha-Druk, 240.

18. Williams, H. G., Pfeiffer, K. A., O’Neill, J. R., Dowda, M., McIver K. L., Brown, W. H. (2008). Motor skill performance and physical activity in preschool children. Obesity (Silver Spring), 16, 121-126.

19. Winnick, J., Short, X. (2014). Brockport Physical Fitness Test Manual-2nd Edition with Web resource: A Health-Related Assessment for Youngsters with Disabilities. Human Kinetics; 2nd edition, 160.

20. Wojnar, J., Macarenco, N., Nawarecki, D., Menshyh, E., Petrenco, Y., \& Pustovalov, B. (2006). Sense-motor reactivity and physical development of schoolchildren. Annales Universitatis Mariae Curie-Sklodowska. Promocja zdorowia w hierarchii wartosci, № 8, 325-331.

Стаття надійшла до редакції 15.10.2019 p. 